\title{
Um "vôo" entre Portugal e Brasil: leituras das relações luso-brasileiras na revista Seara Nova no início dos anos de $1920^{1}$
}

Luciana Lilian de MIRANDA ${ }^{\bullet}$

\begin{abstract}
Resumo: Este artigo busca analisar como a revista portuguesa Seara Nova aborda as relações histórico-culturais estabelecidas entre Portugal e Brasil no início dos anos de 1920. Buscamos ainda recuperar as representações concebidas em torno da idéia das "Pátrias-irmãs", num período de considerável mobilização do Governo português em estreitar as ligações com o Brasil. Dois eventos foram marcantes nesse contexto: a travessia aérea Lisboa-Rio de Janeiro e a visita do então presidente da República, António José de Almeida, ao Brasil, ambos ocorridos em 1922.
\end{abstract}

Palavras-chave: Relações Portugal-Brasil; Revista Seara Nova; Cultura.

\section{Introdução}

A revista Seara Nova expressava as idéias de um grupo de intelectuais republicanos que assumiu um papel de relevo no contexto de crise da I República Portuguesa (1910-1926). Esses intelectuais, conhecidos como "seareiros", propunham um papel de renovação das mentalidades como forma de se reestruturar o regime republicano instaurado.

Pareceu-nos pertinente eleger a Seara Nova para situar as leituras construídas em torno das relações Portugal-Brasil, tendo

\footnotetext{
- Doutoranda em História sob a orientação do Prof. Dr. José Medeiros Ferreira, acerca do tema; "Relações Luso-Brasileiras na I República Portuguesa" - Bolsista da Fundação para a Ciência e a Tecnologia (FCT) - Universidade Nova de Lisboa - 1069-061 - Lisboa - Portugal. E-mail: mirandahist@yahoo.com.br
} 
em vista que a mesma se constituiu como veículo formador de uma opinião pública forte e consciente. Somente uma opinião pública consciente, na concepção do grupo Seara Nova, poderia impor aos políticos o plano de reformas estruturais que a sociedade portuguesa da época necessitava.

Num primeiro momento, propusemos uma síntese a respeito das diretrizes e concepções presentes no grupo de pensadores que se articulou em torno da revista. $\mathrm{Na}$ parte seguinte, concentramo-nos nas leituras presentes na Seara Nova acerca das relações luso-brasileiras.

\section{Algumas considerações sobre a Revista Seara Nova}

Antes de adentrarmos na análise das relações lusobrasileiras registradas na Seara Nova, gostaríamos de fazer uma síntese sobre os propósitos da revista, com ênfase na sua atuação no início dos anos de 1920. Não se devem ignorar os diferentes contextos históricos em que os seareiros se moveram ao longo dos cinquenta e oito anos de existência da revista (1921-1979), cujo formato era mensal, embora nem sempre regular.

O grupo Seara Nova, que teve como principal meio de divulgação das suas idéias a revista, desenvolveu um relevante trabalho de reflexão e pedagogia democráticas. Reuniu em torno da revista várias gerações de prestigiados intelectuais portugueses e um vasto conjunto de colaboradores, cujo contributo estendeu-se pelas diferentes áreas do pensamento humano. Como afirmou Rafael Amaro:

A sua riqueza intelectual e cívica representa mesmo- já o referi noutras ocasiões- um dos mais importantes lugares de memória da luta, em Portugal, pela defesa de uma certa tradição iluminista, cosmopolita, racionalista, em liberdade; contra uma outra parte de nós mais irracional, autoritária e nacionalista ${ }^{2}$. 
A revista surgiu em Quinze de Outubro de 1921, com o firme propósito de renovar toda a elite portuguesa, com o objetivo de denunciar os "males" e propor reformas que pudessem contornar a grave crise da I República (1910-1926). Trata-se de um contexto de instabilidade governativa após a queda do sidonismo ${ }^{3}$ e do rescaldo explosivo dos problemas financeiros, econômicos e sociais do pós-guerra. Deve ser enfatizado, ainda, que aparece em meio a um vazio cultural e político do regime liberal-republicano vigente.

Nesse período, junto da preocupação com a decadência da I República, os seareiros enfrentavam uma crescente simpatia no país pelo nacionalismo organicista e corporativo, representado pela via monárquica do Integralismo Lusitano ${ }^{4}$ ou por segmentos da direita republicana que aderiram ao movimento da Cruzada Nun'Álvares ${ }^{5}$. O Fascismo também atraía os setores mais reacionários da sociedade. A Seara Nova, até o movimento que levou à ditadura militar do 28 de Maio de 1926, combateu esses movimentos conservadores que seduziram uma parcela significativa dos portugueses nos meios intelectuais, políticos e universitários.

A Revista assumia uma aspiração diferenciada no cenário da época. Não representava um órgão de uma corrente estéticaliterária e, nem tampouco, um veículo de doutrinação filosóficocultural. O grupo formado inicialmente por Raúl Proença, Jaime Cortesão, Câmara Reis, Raúl Brandão, Augusto Casimiro, Faria de Vasconcelos, Ferreira de Macedo, José de Azeredo Perdigão e Aquilino Ribeiro (em 1923, também por António Sérgio) visava uma intervenção política suprapartidária.

Os seareiros consideravam-se como uma elite de pensamento e, sendo assim, atribuíam a si próprios a tarefa de "dinamizar um movimento de renovação de toda a elite intelectual portuguesa, que a levasse a assumir o papel de criadora de uma opinião pública forte e consciente, capaz de impor aos políticos o plano de reformas estruturais de que a sociedade portuguesa carecia" ${ }^{6}$, segundo a análise de António Reis. A revista foi escolhida como meio privilegiado de propaganda, no entanto, recorriam ainda à atividade editorial e 
ciclos de conferências como canais de intervenção junto à opinião pública.

Apesar das diferenças de pensamento entre os seareiros, havia um conjunto de princípios que os manteve unidos, sob os papéis protagonistas de Raúl Proença e de António Sérgio na primeira fase da revista, 1921-1926. Tratava-se, portanto, da hegemonia da cultura na ação política e da subordinação da política à moral; da crença na supremacia da razão e na eficácia das idéias enquanto forças privilegiadas de transformação do mundo; o assumido vanguardismo intelectual que atribuía ao aperfeiçoamento das elites a "cura" para todos os problemas presentes na sociedade portuguesa. Havia um profundo empenho idealista em tornar real o ideal, assim como, a total recusa de soluções e concepções jacobinas e materialistas de democracia e de socialismo ${ }^{7}$.

Estas diretrizes permaneceram, em grande parte, até a saída de Sérgio da direção da revista em 1939. Ao assumirem o posicionamento de "extrema esquerda" no seu programa inaugural, apresentado no primeiro número da revista, os seareiros afirmavam-se à esquerda do Partido Democrático Republicano, que monopolizava o poder havia alguns anos. Demarcavam-se ainda contra o jacobinismo, no seu sentido anticlerical e anticatólico, e retomavam o ideal socialista numa concepção reformista e não na perspectiva da socialização da propriedade e da luta de classes, como propunha o Partido Socialista. Não apoiavam os golpes de Estado e as revoluções dessa maneira entendidas, defendiam, sim, uma revolução das mentalidades.

Percebemos, a partir disso, que não se tratava de uma postura de ruptura, mas de uma estratégia de reforma concebida como a melhor maneira de servir à Pátria. Sendo assim, a dialética entre tradição e modernidade encontra-se presente nos princípios propugnados pelo grupo.

A República que se instaurou pela via radical com o apoio da plebe urbana de Lisboa e da Carbonária foi sob a hegemonia dos democráticos de Afonso Costa, entre 1910 e 1917, jacobina, anticlerical e antimonárquica, mas marcadamente conservadora 
nas outras esferas. De acordo com Fernando Rosas, "A República não toca na base material do conservadorismo, na terra, nos negócios, na propriedade, não nacionaliza, não expropria, deixando-o incólume como oligarquia econômicosocial"

Nessa fase, o governo republicano não apresentou propostas relevantes no campo das reformas sociais e tampouco no domínio de estratégias de modernização econômica. Sendo assim, parte da direita incorporou ao discurso da ordem a reflexão estratégica sobre o desenvolvimento do país. Somente no contexto do pós-guerra surgiram reações que puderam ser entendidas como a emergência de uma esquerda republicana. Formulou-se um programa razoavelmente coerente para se atender à realidade do país no que se referia às reformas sociais, à instrução pública, às políticas financeiras e à modernização econômica ${ }^{9}$.

É nesse cenário de organização de uma esquerda republicana, a qual então fará oposição ao projeto antiliberal, anticonstitucional e autoritário das direitas conservadoras, que podemos situar os seareiros, apesar de certas ressalvas. Existe uma polêmica em torno da posição favorável a uma "ditadura" transitória, defendidas por Raúl Proença e António Sérgio, como forma de realizar as reformas necessárias e impedir o avanço do fascismo e da direita conservadora e autoritária no controle do país.

A Seara Nova, segundo Rafael Amaro, foi a principal referência cultural e política de luta contra toda forma de irracionalismos e posições deterministas, quer fossem as mesmas de raça, de classe, de ciência ${ }^{10}$. Este fato é relevante num momento em que os valores e conceitos ligados à modernidade eram questionados na cultura ocidental. Nesse sentido, dentre os movimentos da direita conservadora anteriormente ressaltados, a "Cruzada Nacional Nuno Álvares" representava um antagonista bastante incômodo.

Esta organização agrupou políticos de diversas vertentes num verdadeiro consenso nacionalista, respaldado no renascimento de cultos e mitos das glórias em torno dos heróis 
nacionais. Surgiu no contexto do desastre nacional da grande guerra e de desilusões do sidonismo e apoiou-se no nacionalismo e no cultivo do catolicismo mais conservador. Lembremos que António José de Almeida (presidente da República entre 1919 e 1923, assim como personagem marcante na história do republicanismo português) fez parte da Cruzada desde o seu surgimento, em 1918. Esta atitude lhe renderia críticas por parte da esquerda republicana.

Esse movimento teve um papel importante na oposição da direita católica às forças da esquerda republicana e às instituições da I República. A Cruzada forneceu ainda elementos significativos de fundo simbólico e ideológico que conduziram à ditadura de 1926 e fundamentaram o regime autoritário nacionalista e corporativista do Estado Novo ${ }^{11}$.

É importante acrescentar que a Cruzada, ao difundir a exemplaridade de Nuno Álvares Pereira (santo condestável e beato) operou a síntese de duas expressões de messianismo enquanto função simbólica. Conjugou a tradição providencialista católica do "santo" com a tradição laica republicana do "condestável" ${ }^{12}$. É, sobretudo, nessa segunda dimensão do culto ao condestável, como expressão do nacionalismo messiânico, que podemos compreender a adesão do presidente António de Almeida ao movimento.

Um aspecto original nos seareiros até a década de 1930, período de maior protagonismo de António Sérgio, foi o idealismo com que concebia a luta pela hegemonia da razão como uma missão. Nesse sentido, "assumia-se a Seara Nova como a sede de um grupo de elites iluminadas pela razão, competindo-lhe fazer luz nas consciências de todos os que ainda viviam sob o domínio das trevas"13.

Feita essa síntese, esperamos ter lançado luz sobre as diretrizes que orientavam o posicionamento da revista e o contexto em que a mesma foi fundada, auxiliando na compreensão das leituras construídas em torno das relações entre Portugal e Brasil. Especialmente, na perspectiva da lição educadora e da reforma dos valores propugnados pelos 
seareiros, que ao nosso ver encontram-se presentes nos artigos publicados sobre o tema aqui analisado.

\section{As relações luso-brasileiras nas páginas da Seara Nova}

Ao folhear a revista até 1926, observamos que as relações luso-brasileiras foram abordadas por meio de alguns acontecimentos marcantes e uma secção dedicada às notícias do Brasil. Conforme já referido, dois fatos destacaram-se: a travessia aérea Lisboa-Rio de Janeiro e a visita do presidente António José de Almeida ao Brasil, ambos ocorridos no ano de 1922. Merece ainda a nossa atenção a seção "Bilhetes do Brasil", na qual o jornalista e editor português Álvaro Pinto escrevia comentários e impressões sobre a realidade do país e os eventos mencionados, a partir da sua vivência na então capital brasileira, o Rio de Janeiro.

A primeira referência ao raid aéreo foi esboçada no mês de Abril pelo seareiro Augusto Casimiro em tom de entusiásticas congratulações aos aviadores; o almirante Gago Coutinho e o oficial Sacadura Cabral:

Gago Coutinho e Sacadura Cabral são marinheiros. Pertencem ao número daqueles que em Portugal representam ainda os fortes e nobres ascendentes das épocas heroicas... E vão unir, na curva audaciosa dum largo vôo, Portugal ao Brasil. Bem hajam! Deus os leve e nos dê a alegria de saborear o seu triunfo! Que, graças a êles, Portugal não é apenas truculento egoismo, baixeza solerte, ignorância da Pátria, negação de heroísmo ${ }^{14}$.

Como vimos, a situação era de extrema instabilidade política, que atingiria o seu ápice com a "Noite Sangrenta" de 19 de Outubro de 1921, eco de uma conjuntura já desgastada por conflitos. Nesse acontecimento, foram assassinados três republicanos históricos (Machado Santos, José Carlos da Maia e António Granjo) e as consequências foram profundas no agravamento da crise da República. 
Os preparativos finais para a viagem aérea Portugal-Brasil ocorreram, ainda, sob a sombra desse delicado episódio. O presidente António José de Almeida esteve por renunciar, mesmo após contornar a grave crise acirrada pela "Noite Sangrenta". No entanto, mais uma vez desistiu por uma razão nacional; a travessia aérea Lisboa-Rio. A primeira travessia aérea do Atlântico Sul iniciou-se em trinta de Março e chegou ao destino final (o Rio de Janeiro) em dezessete de Junho de 1922, com várias escalas. Este vôo foi concebido com o intuito de reavivar as boas relações entre os dois povos na altura das comemorações do centenário da independência brasileira.

E foi assim representado o "espírito" desta travessia na carta enviada por António José de Almeida ao então presidente brasileiro; Epitácio Pessoa:

Esta viagem realizada pelo ar vai acrescentar uma nova estrofe à epopeia das viagens que os Portugueses outrora levaram a cabo sulcando os mares. O coração da raça aí lhe vai, Senhor Presidente, conduzido pelas mãos de Heróis numa empresa quase sobre-humana. V. Ex. ${ }^{a}$ o receberá sem dúvida com o carinho fraterno que anima as relações das duas grandes pátrias a que temos a honra de presidir, e por isso lhe ficarei deveras agradecido $^{15}$.

O vôo seria mesmo uma epopéia, com percalços que levariam a substituição do hidroavião por duas vezes. O primeiro incidente grave ocorreu em dezoito de Abril quando houve uma avaria no hidroavião "Lusitânia" junto aos Rochedos de São Pedro e São Paulo, próximo ao Arquipélago Fernando de Noronha, portanto, já em águas brasileiras. Ao saber do acontecido o presidente português expediu a seguinte mensagem aos aviadores: "Jamais um paladino venceu, com menos honra, uma batalha, em virtude de, durante ela, mudar de cavalo"16.

A aventura foi destacada nas primeiras páginas da imprensa portuguesa que enviou repórteres dos jornais; $O$ Século, Diário de Lisboa, O Dia e O Comércio do Porto, a bordo do 
cruzador República, um dos navios que serviu de orientador e apoio no decorrer da viagem.

Percebe-se que a revista Seara Nova dedicou uma atenção especial à travessia ao lançar um número dedicado totalmente ao evento. Uma nota do corpo diretivo sobre o intuito desta edição denota, ao nosso ver, a importância dada à viagem aérea. Foi assim dito: "Em homenagem ao acto realizado pelos dois portugueses Sacadura Cabral e Gago Coutinho, propositadamente deixamos de publicar nêste número as habituais secções de polémica e de política"17, reservando-as para a próxima edição.

Nas imagens, a seguir, percebemos o destaque conferido ao evento pela Seara Nova. Na capa uma caricatura do hidroavião e na página nove, fotos e dedicatórias aos aviadores com o título; "Dois mestres de heroísmo e tenacidade".

Os textos publicados ressaltaram o valor desses dois portugueses, que empreenderam uma conquista tão nobre quanto a da geração dos ilustres marinheiros de 1500. E a partir desse feito, recuperou-se o valor universal dos grandes descobrimentos, com uma nova e genuína contribuição para a humanidade.
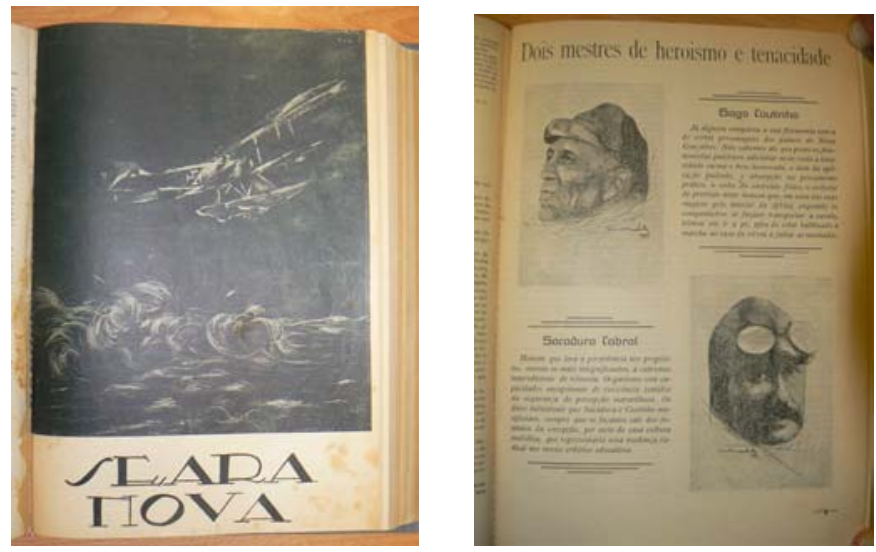
O artigo de abertura da revista, assinado por Jaime Cortesão, recebeu o emblemático título de "Os Novos Lusíadas". Essa atribuição nos parece bastante representativa da imagem que se criou em torno da travessia. A imagética do heroísmo português de outrora, imortalizado nos versos de Camões, aparecem reelaborados em novos tempos, em tempos "modernos":

Como os seus antepassados de Quatrocentos, êstes dois homens hão de sentir que o seu acto é dos que de século em século se propagam. Tal qual as navegações dos seus irmãos nas alvoradas do Renascimento, o seu vôo sublime anuncia aos homens uma nova Primavera da Espécie ... A modéstia e o orgulho, a tenacidade e a disciplina, o método organizador e o espírito de dádiva e sacrifício, o que mais enalteceu o português das velhas eras, ressurge nos dois como uma aparição de espíritos ... De novo os olhos portugueses podem chorar as lágrimas sublimes, e os lábios resar, em paráfrases de glória, os versos dos Lusíadas. Mais uma vez na praia ocidental se talham os padrões que delimitam as idades. 'Ó mundo inteiro volta a alumiar-se com a candeia da pequena casa lusitana!' ${ }^{18}$.

Cortesão insiste no significado universal desta empreitada que ultrapassa o ato político de aproximação entre os dois países. Destaca ainda como principais características dos portugueses recuperadas pelos aviadores; "A modéstia e o orgulho, a tenacidade e a disciplina, o método organizador e o espírito de dádiva e sacrifício". Para o escritor, um feito tão notável que alcançou "o milagre de unificar a consciência nacional no mesmo veemente e heroico entusiasmo" de outrora.

Gago Coutinho e Sacadura Cabral foram considerados "heróis nacionais", no entanto, destacou-se o lado da dedicação e dos estudos exaustivos para o sucesso da empreitada. Para os seareiros, não era apenas talento, ou seja, insistia-se na visão de que a conquista exigiu dedicação, trabalho, disciplina e pesquisa. Estes valores poderiam lançar um novo rumo para a situação do país. Os aviadores "não improvisaram... colheram os frutos de um labor continuado e pertinente" ${ }^{19}$. 
Este seria o traço de diferenciação marcante na mensagem do grupo Seara Nova, que apresentava um projeto de renovação das elites intelectuais e políticas portuguesas.

Para além do entusiasmo e das poesias inspiradas na vitória dos aviadores, buscava-se tirar uma lição moral e educativa do evento. Sendo assim, foram propostos artigos de cunho mais informativo e científico. Um deles relata a viagem experimental, o raid Lisboa-Madeira, ocorrida em vinte e dois de Março de 1921. Esta primeira viagem foi realizada para testar a técnica que seria adotada na travessia Lisboa-Rio. Apresentamse observações de Gago Coutinho, pautadas nos estudos realizados pelo almirante ${ }^{20}$.

Chama-se a atenção para a audácia da viagem, em função dos recursos materiais mínimos; "aeroplano pequeno, com um só motor de fraca potência, um só piloto, um só observador, e sem radiotelegrafia". Apesar disso, é dado destaque para o papel do vôo experimental "como uma contribuição fundamental para os problemas técnicos de que depende a existência, num futuro próximo, de viagens práticas aéreas de longo curso"21. O mérito dos aviadores portugueses estava em serem os primeiros a percorrer uma grande distância sobre o oceano sem indicações externas, todavia com pontos de referência e distâncias previamente calculados.

Simbolicamente, esse primeiro êxito que seria coroado pela travessia do Atlântico Sul até o Brasil, foi apresentado por Sacadura Cabral como um ato de redenção dos portugueses junto às nações mais desenvolvidas da Europa, em especial a Inglaterra. Este sentimento foi expresso no seguinte comentário do aviador ao avistar no meio do percurso Lisboa-Madeira um grande navio inglês (o Avon):

O podermos mostrar diante de estrangeiros que o português, apesar de quanto se possa julgar, é capaz de fazer o mesmo que qualquer outro, é uma sensação agradável que mais profundamente sentem aqueles que o acaso da vida tem feito viajar fora do país ${ }^{22}$. 
A dialética tradição-modernidade emerge nas páginas dedicadas a esse evento, nas quais se alimenta a memória das grandes navegações que é recriada por meio desta nova empreitada. A Cruz de Cristo nos navios de 1500 e no hidroavião Lusitânia (conforme nos mostra a imagem da capa da revista) simbolizava o encontro dessas duas gerações de heróis e a permanência do catolicismo como valor cultural.

O movimento dialético aparece, ainda, no moderno estudo dedicado à aviação que recorreu à clássica ciência portuguesa da navegação marítima. Gago Coutinho adaptou a técnica de navegação marítima (do sextante) para a orientação aérea e criou um novo sextante com horizonte artificial ${ }^{23}$.

Num artigo assinado por Ezequiel de Campos $^{24}$, revela-se um tom mais crítico sobre a travessia aérea. $O$ autor era um assíduo colaborador da revista e importante personagem na concepção de projetos de modernização da economia do país, via desenvolvimento agrícola, divulgados pelos seareiros. Campos não deixa de reconhecer o empenho e sucesso da empreitada, entretanto, questiona o privilegiamento da chamada "Sciência da Posição" como entrave para o desenvolvimento de Portugal:

Portugal há de ser sempre mal-aventurado enquanto não cultivar a sciência da utilização, por obras metódicas, estudando o seu território, distribuindo bem a sua gente no labor profícuo e rendoso, equilibrando a actividade colectiva para um fim nacional humano. Já lá vai o tempo em que a sciência da posição era para nós a primacial. (E por tudo isso mesmo eu rejeitaria o projecto de lei de Álvaro de Castro para as carreiras de navegação aérea: nem somos metalúrgicos de aviões, nem temos gasolina ... e a solução comercial de voar ao Brasil está verdíssima. - Primeiro o pão... $)^{25}$.

Mesmo com todas as homenagens e significados atribuídos ao vôo Lisboa-Rio pelos seareiros, os aviadores considerados heróis nacionais (os "novos Lusíadas") não ficaram isentos de críticas. Raúl Proença não aprovou a postura de Gago Coutinho e 
Sacadura Cabral que permaneceram no Rio de Janeiro durante mais de um mês em jantares, saraus; "como dois bons burgueses dispostos a morder até ao fim a sua bela fatia de glória". E concluiu de forma ácida: "Não há prestígio que resista a trinta dias de jantares, missas campais, bailes, saraus, exibicionismos, discursos de D. Juans parvenus ... Os dois herois, dizêmo-lo francamente, estão-se banalizando e comprometendo" ${ }^{26}$.

Esta atitude banal e excessivamente festiva não condizia com a lição moral e educativa que os seareiros procuraram divulgar sobre o grande feito da travessia aérea. Era necessário manterem-se as imagens de dedicação, trabalho árduo, estudos e pesquisas como valores que poderiam reformar a sociedade portuguesa.

Apesar de possíveis deslizes o grande feito foi comemorado em todo Portugal, segundo a literatura produzida. Nas páginas dos jornais, nos filmes realizados, nas poesias e nas letras de fado. O evento mobilizou todas as forças sociais, produzindo uma construção simbólica em torno do passado glorioso do país, retomado pelos novos desbravadores.

Nem mesmo os graves problemas sociais, políticos e econômicos que acirravam a crise do regime republicano pareciam impedir a mística criada em torno dos heróis da era dos mil e quinhentos, alimentada pelo sucesso da empreitada aérea:

Sobre a agitação dos acontecimentos e sobre as desgraças da terra', a Pátria era a única palavra 'que não envelhecia', dizia nesse dia o fundo do 'Diário de Lisboa' pondo ao alto do cabeçalho os retratos dos dois heróis e, por baixo, os do Infante D. Henrique, 'precursor de Gago Coutinho', e de Álvares Cabral, 'precursor de Sacadura Cabral'. Em Portugal, de Norte a Sul do País, ao que se disse, repicaram festivamente todos os sinos das igrejas... ${ }^{27}$.

Como afirmou Luís Torgal, o sentido nacionalista desta viagem foi capaz de criar à sua volta um verdadeiro entusiasmo nacional. Era uma espécie de paliativo, com grande valor 
simbólico, para curar as "doenças" da República. Constituiu-se, ainda, como passo decisivo para o convite feito pelo presidente do Brasil, Epitácio Pessoa, ao presidente português António José de Almeida para uma visita ao país.

É importante considerar que esse sentimento nacionalista, respaldado na glorificação dos santos e dos cavaleiros da nação portuguesa, assim como, na gesta heróica e evangelizadora das descobertas, revigorou-se na mística triunfal criada em torno da travessia Lisboa-Rio. Isto contribuiu para a hegemonia políticoideológica da direita anti-republicana. Grande parte deste simbolismo, sustentado pelo Integralismo Lusitano e a Cruzada Nun'Álvares, foi incorporado pela matriz ideológica conservadora e autoritária do Estado Novo, fundado nos anos de 1932-33.

O convite feito ao seareiro Jaime Cortesão para integrar a comitiva presidencial ao Brasil foi anunciado com entusiasmo na revista. O escritor era reverenciado como um autorizado representante da cultura portuguesa e das gerações modernas, além de "porta voz" ainda que indireto da Seara Nova neste evento. Nesta mesma matéria, foram assim enunciados os motivos que justificavam a visita ao Brasil:

Pela celebração do centenário da independência, pela necessidade de estreitar relações, afectivas e económicas, com o Brasil, e como coroamento da viagem aérea de Coutinho e Cabral, a embaixada portuguesa tem, nêste momento, a mais transcendente significação política ${ }^{28}$.

É interessante destacar que nos números oito e dezesseis da revista ${ }^{29}$, Jaime Cortesão publicou dois artigos sobre as preparações e os significados da expedição de Pedro Álvares Cabral que conduziu à chegada dos portugueses, em 1500, ao território que se transformou no Brasil. Isto contribuiu para alimentar a memória da relação histórica entre os dois países.

A visita de António José de Almeida teve grande repercussão nos meios nacionais. O Brasil no imaginário português era o filho que se emancipou e soube emancipar-se, 
mantendo unido o imenso território, com muita riqueza a ser explorada.

A base do caráter simbólico encontra-se vinculada à ligação histórica entre os dois países. Deve-se lembrar a importância do Brasil na História portuguesa tanto no passado colonial quanto nas primeiras décadas do século XX. Fora fonte de riquezas e cenário de intensa vivência social com a metrópole e, nos anos de 1920, era o principal território a receber um expressivo contingente de emigrantes portugueses. Os milhares de portugueses que se deslocavam para o Brasil, na sua maioria, alcançavam o sucesso material almejado.

A viagem presidencial não se reduzia a uma situação de nível diplomático, mas implicava no reencontro com o tal "filho emancipado" e de sucesso e o "abraço" às populações portuguesas que emigraram para o Brasil. Podemos acrescentar, ainda, o intuito de conquistar o apoio da rica e poderosa colônia portuguesa ao fragilizado regime republicano.

Segundo António Pedro Vicente, a nação portuguesa era solidária ao presidente António José de Almeida que se manteve fiel às suas simpatias pela República brasileira, desde a sua implantação em 1889. Sendo assim, "defendia a vantagem de uma embaixada democrática ao Brasil" 30 .

No artigo de Quirino de Jesus, colaborador da Seara Nova, percebe-se as representações incorporadas ao ideário português sobre o Brasil. Ao recuperar momentos de ascensão e de declínio de Portugal pautados em marcos da História portuguesa, o autor remete-se ao Brasil como o maior êxito da colonização portuguesa e assim avalia: "Na decadência, que principia no próprio século XVI, fizemos metade da criação que até hoje teve de nós a humanidade. Fizemos o Brasil, uma obra que nem a França no ciclo da sua hegemonia poude igualar".

Mais adiante, diz considerar a emancipação do Brasil como desencadeadora de uma fase de declínio de Portugal, que leva a uma consideração, entre segmentos das elites portuguesas, de que o país estava condenado a reunir-se depois com a Espanha. Ao se referir às relações com as colônias portuguesas africanas comenta: “... Temos Angola, onde há tudo o que é preciso para 
se fazer mais um Brasil, ao pé daquela imensa bacia do Zaire ..." ${ }^{31}$.

Percebemos assim a dimensão simbólica atribuída às relações histórico-culturais entre os dois países nos seus diferentes períodos. Outro elemento marcante nesta visão é a idéia do Brasil como criação, "obra" de maior glória do passado português. Aqui se alimenta o mito de que Portugal inventou o Brasil, escamoteando o contributo das culturas indígena e africana nesta invenção. Desde o final do século XIX, a elite intelectual brasileira buscava desvencilhar-se deste mito e criar uma autonomia cultural; forjar uma identidade brasileira.

O mito da invenção esteve presente nos discursos proferidos por António José de Almeida no Rio de Janeiro. Assim diria o aclamado "tribuno popular" num de seus discursos: “... Mas Portugal tem que agradecer ao Brasil independente de hoje a energia, a bravura, a intelligencia e o amor da raça com que elle tem sustentado, augmentando-a, desenvolvendo-a e doutorando-a de uma maior magestade e belleza, a sua obra, que foi a maior gloria do seu grande passado ..."

A propósito, foi intrigante quando me deparei com uma capa da Revista Seara Nova ( $n^{\circ} .10$, de 15 de Março de 1922) que estampava um desenho sobre a Exposição Internacional, a qual se realizaria no Rio de Janeiro como coroamento das festividades em torno do centenário da independência brasileira. Não havia artigos sobre a Exposição naquela edição e a imagem apresentada despertou a minha atenção. Observemos as figuras a seguir:

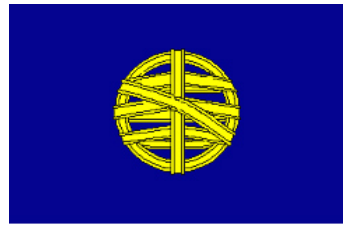

Bandeira do Reino do Brasil dentro do Reino Unido Portugal, Brasil e Algarves (1816-1822)

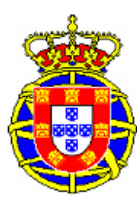

Brasão da Bandeira do Reino Unido de Portugal, Brasil e Algarves (1816-1821) 


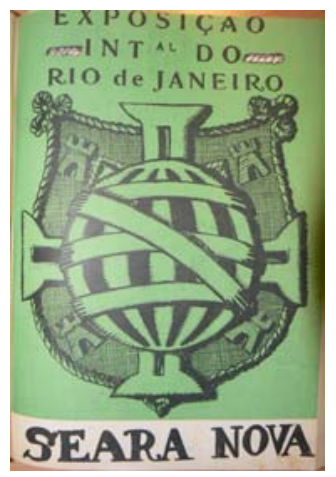

Em primeiro lugar, da esquerda para a direita, temos a capa citada e as bandeiras identificadas ao lado. É perceptível a semelhança entre o emblema apresentado na capa da revista e os símbolos das bandeiras referentes ao período em que o Brasil fora elevado à categoria de Reino no Império Português (18151822). Pareceu-me relevante que tenha sido escolhida esta imagem para representar as relações luso-brasileiras.

Tal imagem nos remete a um momento diferenciado das relações coloniais. Como é sabido, a capital do Reino Português era o Rio de Janeiro e a então colônia brasileira havia ascendido a condição de Reino Unido à metrópole, em 1815. Tratou-se de um período de considerável importância política do Brasil na correlação de forças entre metrópole e colônia. A situação inédita na História do colonialismo europeu de uma colônia transformar-se em capital do Reino, com a mudança da corte portuguesa para o Brasil em 1808, não pode ser negligenciada nas visões construídas sobre as relações entre os dois países, conforme corrobora a historiografia que analisa o período.

A visita presidencial também alimentou essas construções simbólicas. Foi a primeira vez que um chefe de Estado português visitava o Brasil, após a independência em 1822. A sua estadia, de dezessete a vinte e seis de Setembro, foi preenchida por várias visitas e solenidades, tais como: banquetes, visita ao 
Congresso Nacional, recepção no Grêmio Republicano Português, Exposição Universal do Rio, dentre outras.

António José de Almeida consagrou-se com os seus discursos. A beleza e sentido da sua oratória foram registradas pelas imprensas brasileira e portuguesa. $O$ interesse principal dos brasileiros residia na figura de António José, que era popular na colônia portuguesa, e as expectativas foram contempladas, segundo José-Augusto França ${ }^{33}$.

Dessa forma, superaram-se em grande parte os comentários em torno do atraso de dez dias da comitiva presidencial. Como se sabe, a viagem fora concebida para que o presidente e seus convidados pudessem estar presentes nas festividades em comemoração ao dia da Independência brasileira, portanto no dia sete de Setembro, fato que não ocorreu.

Na Secção "Bilhetes do Brasil" escrita à Seara Nova por Álvaro Pinto ${ }^{34}$, que então residia no Rio de Janeiro, surgem impressões sobre a travessia aérea e a visita presidencial, além de vários comentários em relação à realidade brasileira.

Nos seus bilhetes o jornalista escreve que apagados os rumores das festas e comemorações, pode-se reafirmar que a visita do Presidente Almeida "deixou as melhores e mais duradouras impressões". Assim como, foi possível assegurar "não haver a menor separação entre portugueses e brasileiros" ${ }^{35}$.

Registrou as suas impressões sobre o desenvolvimento do Brasil como promissora e com certa dose de idealização. Pinto comenta que sem questão social e com vastíssimos terrenos férteis ... "falando a nossa língua, tendo muito dos nossos costumes, abrigando o maior e mais forte núcleo português", o Brasil tem grandes perspectivas de se tornar a nação mais poderosa da América do Sul. Reafirmou a importância da convenção literária, como um instrumento poderoso de ligação entre os dois povos.

Enfatizou ainda a necessidade de se fortalecer as relações comerciais entre os países. Portugal estava desde a guerra (em referência à primeira guerra mundial), segundo o jornalista, dando maior atenção ao mercado europeu. Assim que os países 
europeus se recompusessem, não mais necessitariam dos produtos portugueses.

Conforme anteriormente mencionado, os discursos do presidente António de Almeida foram bastante emblemáticos, o presidente "fez da palavra a arma fundamental", segundo Luís Torgal $^{36}$. As palavras representaram um recurso poderoso que contrastava com a pobreza material, isto é, a escassez de recursos que marcou a viagem. A diminuta velocidade do paquete $O$ Porto de cerca de 10 nós, devido à má qualidade do carvão $^{37}$ e as declarações da primeira-dama, D. Maria Joana Queiroga, de que não teria acompanhado o marido na visita ao Rio, porque não havia dinheiro para que ela se apresentasse condignamente $^{38}$, ilustram bem tal situação.

O tom conciliador da oratória presidencial buscava acentuar a relação de complementaridade entre os dois países em diferentes momentos da História, reforçando uma visão linear sem tensões e conflitos. Daí sobressai a imagem das "pátrias-irmãs", que se buscou valorizar nesta embaixada realizada com pompa e circunstância.

Os graves problemas financeiros e políticos da República portuguesa, os quais se refletiram nos atrasos da viagem e na inauguração do Pavilhão Português na Exposição Universal do Rio de Janeiro, parecem não ter abalado a sedução exercida pelos discursos presidenciais. Ao comentar os discursos pronunciados por António de Almeida no Brasil, disse o jornal português $O$ Mundo:

Tem havido em Portugal oradores mais castiços mais elegantes mais literários mais académicos do que o sr. António José de Almeida? Não o sei mas o que sei é que nunca houve um orador mais português. Ele representa a nossa raça ele interpreta o sentir do nosso povo não só no seu sentimento sublime na sua intuição maravilhosa mas até nas suas imperfeições... ${ }^{39}$.

A imprensa brasileira também teceu considerações elogiosas sobre a oratória do presidente português ${ }^{40}$. Foi uma embaixada realizada com pompa e com certo sentido de festa 
popular, como desejava António José de Almeida que gostava de falar às multidões. $E$, nesse sentido, o discurso mais popular foi feito na Praça da Independência, junto à Exposição Universal, onde se contabilizou, aproximadamente, trezentas mil pessoas.

A comissão executiva da colônia portuguesa no Brasil reuniu uma verba avultada para ajudar a saldar as despesas envolvidas na viagem e para enviar dinheiro a ser distribuído pelas instituições de caridade em Portugal.

Conforme afirmou Luís Torgal, os resultados práticos da visita presidencial foram poucos. Assinou-se uma convenção literária luso-brasileira, um tratado que isentava do serviço militar em caso de dupla nacionalidade e uma convenção sobre a proteção do trabalho dos emigrantes. No entanto, somente a convenção literária foi contemplada na lei portuguesa de $1^{\circ}$ de Novembro de $1923^{41}$.

O grande significado foi simbólico; a idéia de aproximação entre os dois povos, entre as duas "repúblicas-irmãs". Assim como, a configuração de uma jornada nacionalista e populista, que deixou viva a memória de António José de Almeida no Brasil.

\section{Considerações Finais}

Para além de todas as representações construídas deve-se assinalar que a convivência entre brasileiros e portugueses neste momento no Brasil não era muito amistosa. Há registros de um forte movimento nativista no país. Tal movimento refletia-se nas disputas pelo mercado de trabalho desde o final do XIX e, também, no campo da produção intelectual.

No mesmo período, a notícia da campanha nativista no Brasil também suscitava sentimentos contraditórios em Portugal. Alguns segmentos sociais reagiram a estas situações de "Lusofobia", divulgando as suas críticas a tal movimento. Em 1921, os radicais lisboetas responderam acidamente ao antilusitanismo, chamando os brasileiros de "descendentes da 
macacaria da selva" e avisando de que "com o Brasil ainda podemos bem à vontade" 42 .

A Revista Seara Nova também fez referências ao movimento nativista, como podemos conferir numa nota em saudação ao aniversário da proclamação da República brasileira. Assim foi dito: "Fazendo justiça à grande maioria do povo brasileiro, que repudia os ultrages feitos a Portugal, em nome duma odienda campanha nativista, a SEARA NOVA saúda o Brazil, pela sua festa nacional" ${ }^{43}$.

O passado histórico brasileiro estabelece as "raízes" que ligam o país à tradição cultural português-européia. Seja para romper, negar ou para afirmar as continuidades, o pensamento produzido pela intelectualidade brasileira depara-se com a matriz cultural européia, e em especial, com a cultura portuguesa, responsável pela colonização desta parte da América que se inventou como nação brasileira.

Já dizia o escritor mexicano, Octavio $\mathrm{Paz}^{44}$, que a América nasce como uma utopia européia. Carregamos este legado simbólico; antes de termos uma existência histórica própria, começamos por ser uma idéia européia. "País do futuro", "Novo Mundo"; somos fruto de uma existência premeditada, imaginada e projetada pelo outro.

É nesse campo de tensão entre ser fundado e a ânsia por se fundar que os movimentos intelectuais brasileiros do final do século XIX e as primeiras décadas do século XX devem ser pensados. A elite intelectual brasileira queria reinventar a nação em busca de uma autonomia cultural. Os discursos construídos sobre a formação do Brasil tinham como pano de fundo a busca por uma "identidade nacional" 45 .

A sociedade portuguesa do fim do século XIX e início do XX passava por uma série de transformações, dentre as quais o fim do regime monárquico e a fundação da República em 1910. Todas essas mudanças foram perpassadas pela discussão em torno do "ser português". Nessa época, foram produzidas obras que marcaram profundamente o debate sobre a identidade portuguesa. Foram formuladas idéias, argumentos e símbolos que constituíram essa identidade. Portugal passa por uma 
espécie de (re)fundar numa transição marcada pela dialética tradição-modernidade, impulsionada pelas mudanças no espaço político europeu.

Encontramos proximidades nesses momentos de fundação e (re)fundação vivenciados tanto por Portugal quanto pelo Brasil, o que permitiu novas e velhas leituras reelaboradas sobre o passado comum, assim como, questões que apontam para um distanciamento e ruptura com a tradição histórica lusobrasileira. Pretendemos aprofundar essa discussão no decorrer da nossa pesquisa.

MIRANDA, Luciana Lilian de. A "flight" between Portugal and Brazil: readings of the Luso-Brazilian relations in the Seara Nova magazine in the early 1920s. História, v.28, n.1, p.483-508, 2009.

\begin{abstract}
This article aims to examine how the Portuguese magazine, Seara Nova, addresses the historical and cultural relations between Portugal and Brazil in the early 1920s. We also seek to bring to light the concept designed around the idea of "sister countries", in a period of considerable mobilization on behalf of the Portuguese government to reinforce its links with Brazil. Two events were significant in this context: the LisbonRio de Janeiro transatlantic air crossing and the visit of the former President of the Portuguese Republic, Antonio José de Almeida, to Brazil, both of which occurred in 1922.
\end{abstract}

Keywords: Portugal-Brazil relations; Seara Nova magazine; Culture.

\title{
NOTAS
}

1 Texto elaborado para o Seminário "Modernidade e Tradição Problemática da Modernidade Cultural no Portugal Contemporâneo", ministrado pelo Prof. Dr. António Reis no $2^{\circ}$ semestre de 2006/2007, no 
Curso de Mestrado e Doutoramento em História Contemporânea da Faculdade de Ciências Sociais e Humanas (FCSH), Universidade Nova de Lisboa (UNL).

2 AMARO, António Rafael e outros. Seara Nova Democracia/Razão/Europa: textos e contextos. Porto: Campo das Letras, 2001, pp. 197-198.

3 O Sidonismo foi um regime antiparlamentarista, introduzido por Sidónio Pais em Portugal, durante a primeira República, entre 1917-18, com o apoio do movimento integralista lusitano. O Parlamento tornouse subordinado ao Executivo, em busca de se contornar a instabilidade política do regime republicano, os poderes do presidente foram reforçados, instituindo-se o presidencialismo. A ditadura sidonista, como projeto e experiência política, terminou com o assassinato de Sidónio Pais, em Lisboa, a 14 de Dezembro de 1918. Cf. RAMOS, Rui. "A Segunda Fundação, 1890-1926". In: MATTOSO, José (dir.). História de Portugal, vol. VI. Lisboa: Editorial Estampa, 1994, pp. 522-528.

${ }^{4}$ O Integralismo Lusitano constituiu-se como um movimento sóciopolítico tradicionalista português, com significativa atuação entre 1914 e 1932. Caracterizou-se como força de oposição ao Estado Novo de Oliveira Salazar. Teve origem entre um grupo de exilados católicos e monárquicos na Bélgica, em 1913, iniciando-se como um movimento cultural em reação ao anticlericalismo da Primeira República. Em 1914, o movimento tornou-se político, incorporando republicanos desiludidos, sendo formalmente constituído em Coimbra em 1914, em torno da revista Nação Portuguesa. Opunham-se à República recém-implantada e defendiam uma Monarquia apoiada na representação municipalista e sindicalista, segundo as antigas tradições da Monarquia portuguesa. Cf., RAMOS, Rui. "A Segunda Fundação, 1890-1926", ibid., pp. 473-480.

${ }^{5}$ Trataremos desse movimento na sequência desta parte do texto.

${ }^{6}$ REIS, António. "O Grupo Seara Nova: uma resposta das elites intelectuais à crise do sistema liberal". In: Elites e Poder. A Crise do Sistema Liberal em Portugal e Espanha (1918-1931). Lisboa, Edições Colibri - CIDEHUS-UE, 2004, p. 325.

${ }^{7}$ AMARO, António Rafael, op. cit., pp. 198-199.

8 Conferir, ROSAS, Fernando. Portugal Século XX (1890-1976): Pensamento e Acção Política. Lisboa: Ed. Notícias, 2004, p. 37.

${ }^{9}$ Fernando Rosas, idem, pp. 31-32.

${ }^{10}$ AMARO, António Rafael, op. cit., p. 206.

${ }^{11}$ Cf., LEAL, Ernesto Castro. "A Cruzada Nacional D. Nuno Álvares Pereira e as origens do Estado Novo (1918-1938)". In: Análise Social, nº. 
148, vol. XXXIII, Instituto de Ciências Sociais (ICS), Universidade de Lisboa, 1998, pp. 823-851.

${ }^{12}$ Idem, p. 831.

${ }^{13}$ AMARO, António Rafael, op. cit., p. 208.

${ }^{14}$ A. C. (Augusto Casimiro), "O Raid aéreo Portugal-Brasil", Seara Nova, $\mathrm{n}^{\circ} 11,1 \% / 4 / 1922$, p. 286. Obs.: manteve-se a grafia da época.

${ }^{15}$ Citado em FRANÇA, José-Augusto. Os Anos Vinte em Portugal. Lisboa: Editorial Presença, 1992, p. 61.

${ }^{16}$ Citado em Luís Reis Torgal. António José de Almeida e a República. Lisboa: Círculo de Leitores, 2002, p. 176.

17 "Seara Nova". In: Seara Nova, n 13, 12/05/1922, p. 13.

${ }^{18}$ Jaime Cortesão, "Os Novos Lusíadas", Seara Nova, n 13, 12/05/1922, p. 1.

19 Sebastião da Costa (colaborador), "A Lição do Lusitânia", Seara Nova, $\mathrm{n}^{\circ} 15,1 \% / 7 / 1922$, pp. $44-45$.

20 "Os estudos e experiências preparatórias da viagem aérea LisboaRio", Seara Nova, no 13, 12/05/1922, pp. 2-4 (sem assinatura). Conferir também o artigo de Gago Coutinho; "Algumas considerações sôbre navegação astronómica aérea", escrito em Julho de 1920 e publicado neste número da revista, pp. 4-7.

21 "Os estudos e experiências preparatórias da viagem aérea Lisboa-

Rio", idem, p. 2.

${ }^{22}$ Sacadura Cabral , Seara Nova, no 13, 12/05/1922, p. 10.

${ }^{23}$ Ibid., pp. 2-4.

${ }^{24}$ Ezequiel de Campos (colab.), "A Sciência da Posição e a Sciência da Utilisação", Seara Nova, no 13, 12/05/1922, pp. 12-13, (escrito em 29/04/1922 para Jaime Cortesão).

${ }^{25}$ Idem, p. 13.

${ }^{26}$ R. P., Raúl Proença, "Notas e Comentários: As delícias de Cápua dos aviadores", Seara Nova, $\mathrm{n}^{\circ} 16,1 \% / 8 / 1922$, p. 60.

${ }^{27}$ Citado em FRANÇA, José-Augusto, op. cit., p. 64.

28 "A Missão ao Brasil", Seara Nova, no 17, 1\%/9/1922, p. 73, (sem assinatura).

${ }^{29}$ Conferir, Jaime Cortesão, "A Expedição de Pedro Álvares Cabral e a família dos Marchioni", Seara Nova, no. 8, 15/2/1922, pp. 208-214 e "A partida da armada de Pedro Álvares Cabral", nº. 16, 1\%/8/1922, pp. 4951.

${ }^{30}$ António José de Almeida, Quarenta anos de vida literária e política (1934). Citado em António Pedro Vicente. "A República Portuguesa comemora a independência do Brasil: o significado da viagem de 
António José de Almeida ao Rio de Janeiro". In: Da visão do Paraíso à construção do Brasil. Actas do II Curso de verão da Ericeira. Ericeira, Mar de Letras Editora, 2001, pp. 162-163.

${ }^{31}$ Quirino de Jesus (colab.), “O destino de Portugal”, Seara Nova, $\mathrm{n}^{\circ} 13$, 12/05/1922, pp. 15-16.

${ }^{32}$ Partes do discurso de António José de Almeida no banquete oficial realizado no Catete, Rio de Janeiro, em 18 de Setembro de 1922. In: Discursos do Dr. Antonio José de Almeida (Presidente da Republica Portugueza). Rio de Janeiro: Jacintho Ribeiro dos Santos Editor, 1922, pp. 7-9.

${ }^{33}$ FRANÇA, José-Augusto, op. cit., p. 56.

${ }^{34}$ Álvaro Pinto, editor e jornalista português, participou da criação de importantes revistas no seu país. Foi secretário e diretor da Revista Águia (1912-1921). Emigrou para o Rio de Janeiro em 1920, onde montou uma tipografia denominada "Anuário do Brasil" em parceria com o escritor António Sérgio, como prosseguimento da experiência editorial iniciada em Portugal. O jornalista viveu dezesseis anos no Rio de Janeiro e constitui-se como um ativista do intercâmbio entre os intelectuais lusos e brasileiros. Conferir, SOUZA, Raquel dos Santos M. "Um intelctual imigrante: Álvaro Pinto e o projeto de intercâmbio Portugal-Brasil". Disponível na página: http://www.reseau-ameriquelatine.fr/ceisal-bruxelles/MS-MIG/MS-MIG-3-MADALENO-SOUZA.pdf, consulta realizada em 10/05/2007.

35 "Bilhetes do Brasil", Rio de Janeiro, 5 de Outubro de 1922, publicado na Seara Nova, $\mathrm{n}^{\circ}$ 20, Dez/Jan de 1923, pp. 115-116.

${ }^{36}$ Luís Reis Torgal, op. cit., p. 180.

${ }^{37}$ FRANÇA, José-Augusto, op. cit., p. 56.

${ }^{38}$ Entrevista citada em Luís Reis Torgal, op. cit., p. 37.

${ }^{39}$ Citado em António Pedro Vicente, op. cit., p. 172.

${ }^{40}$ Cf., Jornal A Noite, Rio de Janeiro, 21.9.1922, citado em António

Pedro Vicente, op. cit., pp. 175-176.

${ }^{41}$ Luís Reis Torgal, op. cit., p. 180.

${ }^{42}$ In Radical, 4 de Janeiro de1921. Citado em MATTOSO, José (dir.). História de Portugal, vol. VI. Lisboa: Editorial Estampa, 1994, p. 511.

43 "Ao Brazil", Seara Nova, n 3, 20/11/1921, p. 95, (sem assinatura).

${ }^{44}$ PAZ, Octavio. "Literatura de Fundação", p. 127. Citado em SOUZA, Octávio. Fantasia do Brasil: as identificações na busca da identidade nacional. São Paulo: Escuta, 1994, p. 24.

${ }^{45}$ Gostaríamos de destacar que compartilhamos da idéia de que toda identidade nacional é uma construção simbólica. Não existe uma 
identidade autêntica, mas uma pluralidade de identidades em conflito. Identidades estas construídas por diferentes grupos sociais em diferentes momentos históricos.

Artigo recebido em 01/2009. Aprovado em 03/2009 